\title{
Why Political Contributions Are A Business Issue: State Campaign Finance Reform And The Bottom Line
}

\author{
Amy Handlin, Ph.D., Monmouth University, USA
}

\begin{abstract}
While electoral finance reform has finally taken hold at the national level -- due partly to pressure from the corporate community -- this paper argues that reform at the state level is equally critical to business. The current system is costly both in dollars and in the perception of corruption, but is amenable to change.
\end{abstract}

Keywords: Ethics; Corruption; Politics; Government; Campaign Finance Reform

\section{BACKGROUND AND INTRODUCTION}

$\mathrm{n}$ the 1980s and 1990s, Washington DC was a hotbed of proposals for national campaign finance reform.
There was widespread recognition that as spending by candidates and political parties had skyrocketed,
ordinary citizens had increasingly been priced out of meaningful participation in the electoral process (Cabot and Sheekey, 1990). By 1998, the average cost of running for federal office had risen to $\$ 500,000$ for a seat in the House of Representatives and $\$ 3.8$ million for a seat in the U.S. Senate.

Of more immediate concern to the business community, the annual contributions of corporate Political Action Committees to various partisan coffers had reached $\$ 78$ million -- and were primed to rise to much higher levels. Business leaders were beginning to realize that the situation was corrosive to democracy and thus to the fundamental government institutions that ensure a free and fair marketplace (CED 2005).

A decade of congressional debate culminated in passage of the Bipartisan Campaign Reform Act of 2002 an unprecedented set of restrictions on campaign-related activities by corporations as well as labor unions on the federal level. A particular target of the BCRA was the stream of so-called "soft money" contributions that previously flowed, essentially without regulation or oversight, from business entities and unions to the Democratic National Committee, the Republican National Committee and a range of other party-building or -recruiting organizations (Bizzell, 2008).

The 2004 national elections were the first to feel the effects of BCRA. While other problems arose -- for example, large amounts of "soft money" were redirected to independent issue advocacy groups -- it was clear that a sea change had occurred. As summarized in one report: "Corporate executives are no longer being 'shaken down' by elected officials and party leaders for soft money contributions, parties have turned their focus toward grassroots fundraising and campaigns are actually raising more money than ever before" (CED 2005, p. 1).

In 2006 and 2009, the U.S. Supreme Court invalidated certain political contribution limits on free speech grounds. In 2010, the landmark Citizens United v. Federal Election Commission decision struck down the BCRA prohibition on corporate funding for political ads and loosened several other restrictions. It also paved the way for so-called "SuperPACs" - political committees that may spend unlimited amounts of money but must operate independently of any candidate's campaign (Citizens United v. Federal Election Commission 2010). However, corporations are still barred from donating directly to candidates, thus preserving a significant disincentive for politicians to "shake down" business people in return for influence, favors or contracts. 
But in spite of a decade of historic reforms in Washington, relatively little has changed in the rules that govern political fundraising on the state level. In some cases, business-specific campaign finance restrictions for state legislative and/or executive candidates are tighter than for federal candidates. In others, there are virtually no limits on political fundraising. The rules are wildly inconsistent not only from state to state, but sometimes on different levels of government in the same state; in other words, a town or city may impose its own restrictions on top of county and state regulations.

For example, four states ban all corporate political contributions; five states impose no restrictions at all. In Pennsylvania, Ohio, Michigan, Texas and eight other states, employees or officers of a corporation may donate to a registered political action committee but not directly to candidates. Where contribution limits exist, they can vary from a few hundred dollars to over $\$ 5,000$.

Because of the diversity and complexity of state regulations, it is hard to isolate one set of problems and potential solutions that would be of equal importance to all. What is clear is that businesses have a stake in statelevel reform, at least as large as in federal reform, for two key reasons:

1. the absolute cost to businesses of political contributions to state candidates and party organizations during an economic downturn

2. the real and/or perceived corruption associated with those contributions

The purpose of this paper is to stimulate interest among business leaders (and business educators) in the campaign finance issues important in states where they have operations, customers, vendors and other stakeholders. One of the most common of these issues is pay-to-play - the imposition of limits on political contributions by firms holding (or bidding for) public contracts. To illustrate its impact, the experience of New Jersey is described below. While New Jersey has become somewhat notorious for political corruption, wasteful spending and unsavory campaign practices of many kinds (chronicled in the 2008 bestseller The Soprano State), it is also a laboratory for recent reform initiatives that are being monitored closely by other states.

\section{PAY TO PLAY: THE NEW JERSEY EXAMPLE}

\section{Cost of Political Contributions on the State Level}

In the wake of BCRA, corporate political action committees sharply reduced their contributions to federal political parties and committees; but at the same time, they increased their contributions to political organizations at the state level. In the 2003-2004 election cycle, only 25 percent of corporate political donations went to federal entities, while 67 percent were directed to state entities (Public Affairs Council 2005). The remainder went to campaigns for or against ballot propositions in states with initiative and referendum laws.

Most of these donations fell into the category defined as "interested money" (Milyo, Primo and Groseclose, 2000); in other words, they came from businesses that are generally unregulated and/or heavily dependent on government contracts. Because good relationships with elected officials are the lifeblood of such enterprises, their leaders have long been vulnerable to pressure, threats and simple fear that a competitor's checks will buy him better access or more favorable treatment.

While formal quid pro quos are illegal, essentially amounting to bribes or kickbacks, this informal system of influence-buying exists in some form in every state. Dubbed "pay-to- play", it was finally targeted for reform in New Jersey after years of documented extortion and other crimes linked to the system.

In 2005, the New Jersey legislature banned contributions over $\$ 300$ to political candidates or committees from businesses with public contracts of $\$ 17,500$ or more. The restrictions apply to municipal, county and state government. The ban is far from airtight; for example, a company can contribute over $\$ 300$ to candidates on the municipal level and receive a contract on the state level, or the other way around. Additionally, it is a fairly simple process to obtain an exemption from the ban for certain types of contracts. 
Despite such loopholes, the data show significant change in political giving patterns in the wake of the restrictions. During 2004-2005 -- one year before the new law took effect -- total contributions reported to the New Jersey Election Law Enforcement Commission rose 16.99 percent. However, during 2005-2006, there was a dramatic reversal - total contributions dropped 11.81 percent. As an example, one of the largest engineering firms in the state gave over $\$ 55,000$ to candidates and political committees in 2005; by 2007 - the first year of legislative elections after passage of the law - its contributions were down to \$2,700 (NJ Election Law Enforcement Commission, 2008).

Some major companies - formerly big donors to campaigns - stopped giving money altogether. According to one press report, "Many of New Jersey's major contractors have slashed or stopped their donations to political fundraising committees. For example, one-third of the money the Democratic State Committee raised in 2004 came from contractors, while last year it was just six percent" (Associated Press 2006, p. 26).

In 2007, according to ELEC records, 1,669 New Jersey businesses made contributions totaling $\$ 15.2$ million, for an average per-entity cost over $\$ 9,000$. This is still a nontrivial bite out of revenues, especially in the midst of a severe economic slowdown; but it can be assumed that the magnitude of these expenditures would have been considerably higher before the restrictions took effect (Note: Because there were no equivalent disclosure requirements before the pay-to-play ban, there exist no comparable data from earlier years.) By 2010, political donations by public contractors in the state hit their lowest level in five years, down 13 percent from the year before (NJ Election Law Enforcement Commission, 2011).

\section{The Corruption Perception}

Beyond the financial burden, businesses can be hurt by the whiff of impropriety, even illegality, associated with pay-to-play. To document this corruption perception, the Prudential Business Ethics Center at Rutgers University commissioned a study in 2006. Among its findings, "Business leaders are nervous about New Jersey's reputation [for corruption] which, they feel, is an embarrassment and may adversely affect their credibility with B to B relations and corporate relocation decisions...The leading reform advocated by interviewees was campaign finance reform" (Peterson 2007, p. 16).

Study participants clearly made the point that reform is not only about saving them money; it is also about maintaining their competitiveness in a regional, as well as global, marketplace. "New Jersey needs to be perceived as a better place to do business than Pennsylvania, but we are not managing our culture well", commented a corporate director (Ibid. p. 4).

Along the same lines, the New Jersey Business and Industry Association identified pay-to-play reform as one of twelve key priorities in its 2008 "blueprint for building a strong private-sector economy in New Jersey" (NJBIA, 2008). The association called for "More ethics reforms to ensure that government is conducted in a transparent and open process, and that contracts are provided on the basis of merit" (Ibid.) Since 2008, the group has consistently reaffirmed this position.

\section{DISCUSSION AND RECOMMENDATIONS}

The concerns of businesses in New Jersey are mirrored in national reform proposals and exacerbated by current economic challenges. In a white paper titled Building on Reform: A Business Proposal to Strengthen Election Finance, the U.S. Committee on Economic Development commented:

As business leaders, we are also concerned about the effects of the campaign finance system on the economy and business. Americans identify "special interests" principally with corporations. A vibrant economy and well functioning business system will not remain viable in an environment of real or perceived corruption, which will corrode confidence in government and business. If public policy decisions are made -- or appear to be made -- on the basis of political contributions, not only will policy be suspect, but it's uncertain and arbitrary character will make business planning less effective and the economy less productive. In addition, the pressures on businesses to 
contribute to campaigns because their competitors do so will increase. We wish to compete in the marketplace, not in the political arena (CED p. 1).

These concerns are not only broad-based but also durable, having been voiced as early as 1990 . Having documented increasing demands on corporate PACs in the 1980s, two leading critics summed up the problem: "In a democracy, there is a bottom line below the bottom line: the preservation of democracy itself" (Cabot and Sheekey, 1990).

As New Jersey's experience suggests, the problem - while still serious - is not intractable. Business educators, researchers and leaders can help spur positive change.

- $\quad$ Educators can train managers, especially in MBA and executive development programs, to recognize the problem and be open to solutions. In particular, professors can address these issues in the context of business ethics courses, modules and assignments.

- $\quad$ Researchers can help quantify the "corruption tax" on both businesses and individuals - that portion of state and local revenues wasted when overpriced public contracts are awarded in return for political contributions. They can also collect and analyze data necessary to compare the effectiveness of different approaches to reform.

- Business leaders can use industry associations and networks to pressure public officials for legislative reform and work with the media to publicize the adverse economic impacts of the current system. On an industry-by-industry basis, they may also consider voluntary political contribution limits that are lower than allowable maximums and will be adhered to by major players in the industry.

\section{AUTHOR INFORMATION}

Amy Handlin, Ph.D. is Associate Professor in the Department of Marketing and International Business at Monmouth University. She studies small business lobbying and business-government relationships. E-mail: ahandlin@monmouth.edu

\section{REFERENCES}

1. $\quad$ Associated Press (2006), "Contractors Slash Political Donations," Courier News June 12, 26.

2. Bizzell, Wesley (2008), "Leader of the PAC: Corporate Guidelines for Political Contributions," The Metropolitan Corporate Counsel, www.metrocorpcounsel.com

3. Buell, Barbara (2001), "PAC Contributions: Mistrust is Misplaced," Stanford Business 69 (2), 1.

4. $\quad$ Cabot, Edward and K. Sheekey (1990), "Let's Send Corporate PACs Packing," Business and Society Review 72 (Winter), 62-64.

5. $\quad$ Citizens United v. Federal Election Commission 558 U.S. 08-205 (2010).

6. Committee for Economic Development (2005), Building on Reform: A Business Proposal to Strengthen Election Finance," www.ced.org

7. Franzese, Paula and D. O'Hern (2005), "Restoring the Public Trust: An Agenda for Ethics Reform of State Government and a Proposed Model for New Jersey," Rutgers Law Review 57 (4), 1175-1233.

8. Lu, Adrienne and J. Reitmeyer (2007), "Pay to Play Trail Easier to Follow," The Bergen Record Oct. 11, 40-41.

9. Milyo, Jeffrey, D. Primo and T. Groseclose (2000), "Corporate PAC Campaign Contributions in Perspective," Business and Politics 2 (1).

10. New Jersey Business and Industry Association (2008), "Public Policy Principles and Priorities," www.njbia.org

11. New Jersey Election Law Enforcement Commission 2007-2008 database, www.elec.state.nj.us

12. New Jersey Election Law Enforcement Commission 2009-2010 database, www.elec.state.nj.us

13. Peterson, Barrie (2007), "New Jersey State Government Ethics Reform: Business Leaders and the Public Call for Change," Rutgers Prudential Business Ethics Center (Nov.), New Brunswick, NJ.

14. Public Affairs Council (2005), Corporate PAC Benchmarking Project 2003/2004 and 2005/2006, Impact (Sept.), Washington DC. 